instinctively associate with the tropics, contentedly buzzing about the salmon berries and appearing as unconcerned and happy as if his fine wings had not carried him some thousands of miles from his winter quarters in southern California or Mexico. I cannot imagine a more wonderful instance of bird migration than this-one of the smallest known birds, no larger than a fair-sized moth, yet with strength, endurance, and intelligence to travel up and down the greater part of the North American coast line, pressing close upon the train of early spring, awaiting only the blooming of the wild currant in California and the salmon berry farther north, to venture upon his perilous way !"

What erroneous deductions as to the climate of an "inter-glacial period" would probably be drawn if the remains of a humming-bird were found in a peat bed between deposits derived from glaciers!

The "Forests of Alaska" are described by Prof. B. E. Fernow (pp. 235-256), who points out that their economic value has been much over-estimated. He notes "the astonishing indifference to the influence of the near-by ice-masses "shown by the trees growing in close proximity to some of the great glaciers and even upon their surfaces where covered by moraine material. This article contains some interesting observations on the propagation and spread of forest growth.

The general geography and physiography of the territory are the subject of a lucid article by Mr. H. Gannett (pp. 257-277). In mentioning that the present glaciers are "only trifling fragments" of the great glaciers which occupied this region a short time ago, it is remarked that, nevertheless,

"all the glaciers of Switzerland together would form but a few rivulets of ice on the surface of the Muir Glacier, and the Muir is but one of many glaciers of equal magnitude."

All observers of the glacial phenomena of the region will probably agree with Mr. Gannett that the period since the retreat of the ice from the present water-channels of the coast cannot have been long. It is evident that in Alaska, as in several other glacier-fields of the globe, if the existing ice were entirely removed, few of the glaciers could ever regain their present dimensions under the climatal conditions which now prevail. And it seems probable that in some degree the present glaciers represent the lingering remnants of the great ice-fields of the Glacial period.

"The Alaska Atmosphere" is dealt with by Prof. W. H. Brewer (pp. 279-289), who lays especial stress upon the effects produced by the relatively dustless condition of the air.

An article on "Bogoslof, our Newest Volcano," by Dr. C. H. Merriam (pp. 291-336), copiously illustrated with views of the two new volcanic islands at various periods in their history, and provided with a bibliographical appendix, will appeal to every volcanist.

In describing "The Salmon Industry" (pp. 337-355), which has attained such gigantic proportions in Alaska, Dr. G. B. Grinnell once more calls attention to the wretchedly wasteful methods adopted by the salmon canners in defiance of Congressional laws which there is scarcely a pretence of enforcing, and to the consequent extraordinarily rapid depletion of supplies supposed at first to be inexhaustible. It is the common story of the white pioneer in every part of the globe :-

"All these people recognise very well that they are destroying the fishing; and that before very long a time must come when there will be no more salmon to be canned at a profit. But this yery knowledge makes them more and more eager to capture the fish and to capture all the fish. This bitter competition sometimes leads to actual fighting - on the water as well as in the courts. A year or two since, one company which was trying to stop another from fishing on ground which it claimed as its own, sent out its boats with immense seines, and dropping them about the steam launches of its rival tried to haul them to the shore. . . Thus the canners work in a most wasteful and thoughtlessly selfish way, grasping for everything that is within NO. I 703 , VOL. 66$]$ their reach and thinking nothing of the future. Their motto seems to be, "If I do not take all I can get somebody else will get something." "

The final article of the book, however, reveals the pioneer in the unaccustomed rôle of conservator. It consists of a highly interesting account, by Mr. M. L. Washburn, of "Fox Farming in Alaska" (pp. 357-365), a new industry which in itself is a striking illustration of western resourcefulness and may lead to important future developments.

"Something like fifteen years ago a few men in western Alaska, realizing that fur-bearing animals were doomed, decided to try the experiment of propagating some of the more valuable kinds. Having resided on the Seal or Pribilof Islands and observed that the blue fox became somewhat tame, they resolved to try its domestication by placing a small number on protected islands and caring for them as the stockman cares for his herd of cattle or sheep. About twenty foxes were taken from St. Paul Island of the Pribilof group, and placed on North Semidi, one of the hundreds of unoccupied islands of Alaska, and thus the experiment began. . . From North Semidi, the original 'fox-ranch,' if one may employ such a term, foxes were taken to other islands along the Alaska coast and the experiments continued. The results though sometimes discouraging and not always financially successful, have shown on the whole that the animal could be raised and its valuable pelt obtained with as much regularity as in the case of the humbler domestic animals. About thirty islands are now stocked with blue foxes-all the outgrowth of the small stock of twenty foxes taken from St. Paul Island fifteen years ago."

A description is given of one of these ranches where there are now 800 to 1000 foxes. The animals soon learn to recognise their keepers and come to know the feeding time, gathering round for their daily allowance, and afterwards scattering about the island until the time for the next day's dinner. In short, the blue fox has been added to the list of domesticated animals. The probable outcome is thus stated:-

"It is believed that the time is not far distant when hundreds of the now useless islands of Alaska will be utilised in the propagation of fur-bearing animals, and that many of the farmers of the Northern States [let Canadians take note!] will have wire-fenced enclosures of an acre or two devoted to this industry, from which they will reap a far greater return than from all the rest of their live stock."

For the excellency of the paper, printing, illustrations and binding, as well as for their contents, these volumes are indeed highly to be commended. As an instance of rare unobtrusiveness and good taste we may mention that in spite of its almost immoderate wealth of illustration not a single portrait of Mr. Harriman or of any member of his family party is to be found in the work.

That the literary and scientific members of this summer cruise should have occasionally burst into song causes us no surprise ; and the sprinkling of verse in the volumes is distinctly pardonable in the circumstances.

$$
\text { G. W. L. }
$$

\section{OBSERVATIONS OF VOLCANIC ACTIVITY IN THE WEST INDIES.}

FURTHER details of the recent volcanic eruptions at Martinique and St. Vincent continue to reach us through West Indian and other papers. Though the great eruptions of Mont Pelée and the Soufrière occurred on May 7-8, the Dominica Guardian states that shocks of earthquake were felt so far back as February of last year. These disturbances were noticed several times during the year, and were regarded as serious in February of this year. From April 20 also until the eruption, rumbling sounds were frequently heard, especially at Fancy and at Frasers. Nineteen shocks were experienced within half an hour on May 3 at Wallibou, 
and the disturbances became more noticeable as the days went on, until, on May 5 , the Soufricre gave definite warnings of its renewed activity. The Rev. J. H. Darrell, writing from Kingstown, St. Vincent, on May 9, gives, in the lominica Guardian, the following account of the subsequent eruptious of this volcano:-

It was on Tuesday, May 6 , at 3 p.m., that the mountain commenced its series of volcanic efforts. A strong shock of earthquake, accompanied by a terrible noise, occurred, and the volcano began to emit steam. At 5 p.m. louder and more frequent explosions were heard, the detonations succeeding each other at rapidly diminishing intervals. At 7.30 p.m. columns of steam issued from the old crater with terrific noise. These lasted until midnight, when another heavy explosion occurred.

At 7 a.m. on Wednesday, May 7, there was another sudden and violent escape of pent-up steam, which continued ascending until Io a.m., when other material began to be ejected. It would seem that this was the time when the enormuus mass of water in the lake of the old crater was emitted in a gaseous condition. By I2 o'clock noon it appeared that there were three craters vomiting lava - the old crater that had contained the lake, the second crater that opened in 1812 , and a thirc crater that had burst open in the present eruption. Six dis tinct streams of lava were visible, running down the sides of the mountain. The mountain heaved and laboured to rid itself of the burning mass of lava heaving and tossing below. By 12. 30 p.m. it was evident that it had begun to disengage itself of its burden by the appearances as of fire flashing now and then around the edgre of the crater. There was, however, no visible ascension of fiame. These flame-like appearances were, I think, occasioned by the molten lava rising to the neck of the volcano. Being quite luminous, the light emitted was refiected from the banks of steam above, giving them the appearance of flame.

From the time the volcano became fully active, tremendous detonations followed one another so rapidly that they seemed to merge into a continuous roar which lasted all through the night of May 7 and up to 6.30 a.m. on May 9. These detonations and thunderings were heard as far as Barbados, Ioo miles distant, as well as in Grenada. Trinidad and the south end of St. Lucia. At 12.10 p.m. I left in company with several gentlemen in a small row boat to go to Chateaubelair, where we hopel to get a better view of the eruption. As we passed Layou, the first town on the lceward coast, the odour of sulphuretted hydrogen was very perceptible. Before we got hail way on our journey a vast column of steam, smoke and ashes ascended to a prodigious elevation. The majestic body of curling vapour was sublime beyond imagination. We were about eight miles from the crater, as the crow flies, and the top of the enormous column, eight miles off, reached higher than one-fourth of the segment of the circle. I judge that the awful pillar was fully eight miles in height. We were rapidly proceeding to our point of observation, when an immense cloud, dark, dense, and apparently thick with volcanic material, descended over our pathway, impeding our progress and warning us to proceed no further. This mighty bank of sulphurous vapour and smoke assumed at one time the shape of a gigantic promontory, then appeared as a collection of twirling, revolving cloud-whirls, turning with rapid velocity, now assuming the shape of gigantic cauliflowers, then efforescing into beautiful flowershapes, some dark, some effulgent, others pearly white, and all brilliantly illuminated by electric flashes. Darkness, however, soon fell upon us. The sulphurous air was laden with fine dust that fell thickly upon and around us discolouring the sea; a black rain began to fall, followed by another rain of favilla, lapilli and scorix.

The electric flashes were marvellously rapid in their motions and numerous beyond all computation. These with the thundering noise of the mountain mingled with the dismal roar of the lava, the shocks of earthquake, the falling of stones, the enormous quantity of material ejected from the belching craters, producing a darkness as dense as a starless midnight, the plutonic energy of the mountain growing greater every moment combined to make up a scene of horrors. It was after five o'clock when we returned to Kingstown, cowed and impressed by the weirdness of the scene we had witnessed, and covered with the still thickly falling grey dust. Of what this material is composed I am unable to give a certain opinion; but it appears to consist of comminuted rock, prouluced by attrition of the material as in successive outbursts it is hurled aloft and then tumbles back again to the burning crater to be ejected finally as impalpable dust. So minute are the particles that they find their way through the finest chinks of a closed room. large areas of cultivation have been buried under the fall of the dust. Its effects upon vegetation will probably be beneficial ultimately, but in the nieantime great suffering as well as inconvenience is occasioned thereby. The awful scene was renewed yesterday (May 8) and again to-day. At about 8 a.m. the volcano shot out an immense volume of material which was carried in a cloud over Georgetown and its neighbourhood, causing, not only great alarm, but compelling the people by families to seek shelter in other districts.

More than 400 lives have been lost on the windward side of the island, chiefly from lightning, and we have not yet heard from other parts of the island in that neighbourhood. The flowing lava on the leeward side of the mountain has buried up the Vallibou and Richmond villages and estates, while on the windward side of the mountain the estates of Lot Fourteen, Rabacca, Overland, Touraina, Orange IIill, Mount Bentinck, Langely Park and portions of others have been obliterated.

It is now 2 p.m. (May 9). A dense gloom still envelops the mountain, but there has been no further eruption since $8 \mathrm{a} . \mathrm{m}$. Several streams and rivers have dried up in various parts of the island, and we are threatened with a water as well as a food famine.

As already announced, the National Geographic Socfety of Washington has sent a special expedition to Martinique and St. Vincent to investigate the volcanic conditions of the West Indian regrions. The members consist of Mr. Robert T. Hill, of the U.S. Geological Survey ; Prof. Israel C. Russell, professor of geology in the University of Michigan, Ann Arbor; Commander C. E. Borchgrevink, the Antarctic explorer; Dr. T. A. Jaggar, of Harvard University; Mr. G. C. Curtis, of Cambridge, U.S.A., and Dr. Angelo Heilprin, president of the Philadelphia Geographical Society.

The expedition is one of the most important and best equipped commissions ever sent out to study actual volcanic action. Results of scientific and practical consequence may therefore be expected from the work of the members of the party. On their return to the United States they will report the results of their observations to the National Geographic Society. This report, forming a series, will be published in full in the journal of the Society, the National Geographic Magazine, the June number of which contains a preliminary account of the observations already made.

Upon arriving at Martinique, Dr. Hill embarked on a steamer and examined the coast as far north as Macouba Point, the north end of the island, making frequent land. ings. After landing at Le Prêcheur, a little village five miles north of St. Pierre, he walked through an area of active volcanism to the destroyed city. 1)r. Hill, according to the Associated Press despatches from Fort de France, was the first man to set foot in the active area of craters, fissures and fumaroles.

On his return to Fort de France he issued a brief statement as to his observations to the National Geographic Society, and it is here abriged from the Society's magazine.

The zone of the catastrophe in Martinique forms an elongated oval, containing on land alout eight square miles of destruction. This oval is partly over the sea. The land part is bounded by lines running from Le Prêcheur to the peak of Mont Pelée, thence curving around to Carbet. There were three wellmarked zones:-

(I) A centre of annihilation, in which all life, vegetable and animal, was utterly destroyed. The greater northern part of St. Pierre was in this zone.

(2) A zone of singeing, blistering flame, which also was fatal to all life, killing all men and animals, burning the leaves on the trees, and scorching, but not utterly destroying, the trees themselves.

(3) A large outer, non-destructive zone of ashes, wherein some vegetation was injured.

NO. $17 \mathrm{O}_{3}$, voL. 66j 
The focus of annihilation was the new crater, midway between the sea and the peak of Mont Pelée, where now exists a new area of active volcanism, with hundreds of fumaroles, or miniature volcanoes.

The new crater is now vomiting black, hot mud, which is falling into the sea. Both craters, the old and new, are active. Mushroom-shaped steam explosions constantly ascend from the old crater, while heavy ash-laden clouds float horizontally from the new crater. The old one ejects steam, smoke, mud, pumice and lapilli, but no molten lava.

The salient topography of the region is unaltered. The destruction of St. Pierre was due to the new crater. The explosion had great superficial force, acting in radial directions, as is evidenced by the dismounting and carrying for yards the guns in the battery on the hill south of St. Pierre and the statue of the Virgin in the same locality, and also by the condition of the ruined houses in St. Pierre.

According to the testimony of some persons, there was an accompanying flame. Others think the incandescent cinders and the force of their ejection were sufficient to cause the destruction. This must be investigated.

On Monday, May 26, Dr. Hill started on horseback from Fort de France for Morne Rouge and Mont Pelée. He reached Morne Rouge safely on May 27, where he succecded in getting a number of photographs. A close approach to Mont Pelée was impossible, so he started back in a southerly direction. During the two nights he was camping out he made some important observations of volcanic action, and on his return issued the following statement :-

My attempt to examine the crater of Mont Pelée has been futile. I succeeded, however, in getting very close to Morne Rouge. At 7 o'clock on Monday evening I witnessed from a point near the ruins of St. Pierre a frightful explosion from Mont Pelcee, and noted the accompanying phenomena. While these eruptions continue no sane man should attempt an ascent to the crater of the volcano. Following the salvos of detonations from the mountain, gigantic mushroom-shaped columns of smoke and cinders ascended into the clear, starlit sky, and then spread in a vast black sheet to the south and directly over my bead. Through this sheet, which extended a distance of ten miles from the crater, vivid and awful lightning-like bolts flashed with alarming frequency. They followed distinct paths of ignition, but were different from lightning, in that the bolts were horizontal and not perpendicular. This is indisputable evidence of the explosive oxidation of the gases after they left the crater. This is a most important observation, and it explains in part the awful catastrophe. This phenomenon is entirely new in volcanic history.

I took many photographs, but do not hesitate to acknowledge that I was terrified.

Nearly all the phenomena of these volcanic outbreaks are new to science, and many of them have not yet been explained. The volcano is still intensely active, and I cannot make any predictions as to what it will do.

Associated Press messages from Martinique, dated May 3I, announced that Prof. Heilprin had succeeded in climbing to the top of the crater of Mont Pelee. The despatch is as follows :-

Prof. Angelo Heilprin this morning ascended to the top of the crater on the summit of Mont Pelée.

The expedition left Fort de France last Thursday, May 29, at noon. Friday was spent in studying the newly formed craters on the north flank of the mountain. Saturday morning Prof. Heilprin determined to attempt the ascent to the top of the crater, and with this purpose in view he set out at five o'clock.

The volcano was very active, but Prof. Heilprin reached the summit and looked down into the huge crater. IIere he spent some time in taking careful observations. He saw a huge cinder cone in the centre of the crater. The opening of the crater itself is a vast crevice 500 feet long and 150 feet wide.

While Prof. Ieilprin was on the summit of the volcano, several violent explosions of steam and cinder-laden vapour took place, and again and again his life was in danger. Ashes fell about him in such quantities at times as to obscure his vision completely.

No. I703. voL. 66]
Prof. Heilprin found that the crater at the head of the River Fallaise has synchronous eruptions with the crater at the sunmit of the volcano, and that it ejects precisely the same matter at such times.

On May $3^{\mathrm{I}}$ a party consisting of Prof. Jaggar, of Harvard University, Dr. Hovey, of the American Museum of Natural History of New York, and Mr. George C. Curtis, ascended to the summit of the Soufrière of St. Vincent from the western side.

The ascent was exceedingly difficult, owing to the mud that covered the mountain side, but the ground was cold. After a tiresome scramble up the slippery hill, the rim of the old crater was reached about midday. There was no trace whatever of vegetation, but there had been no change in the topographical outlines of the mountain on that side, and the old crater re. tained its ragic beauty. The great mass of water that formerly lay serenely about 500 feet below the rim of the crater had disappeared, and the crater appeared to be a dreadful chasm more than 2000 feet deep. With the aid of a glass, water was made out at the bottom of this abyss.

The party did not venture across the summit of the Soufriere to inspect the new crater, which was then emitting a little vapour, for the ground in that direction looked to be dangerous.

Apparently the ridge of the mountain, called "The Saddle," was intact, although the old crater seemed of larger circum. ference than before the recent eruption. At the western base of the Soufrière a subsidence of a depth of 100 feet occurred for an area of a square mile. The bank of volcanic dust that prevents the sea encroaching farther inland at Wallibou is being gradually washed away. The lava beds on the eastern side of the Soufriere continue to emit steam, respite the protracted and heavy rainfall that has occurred.

Mr. Knight, Senator for Martinique, has arrived in Paris, and a few of his observations of the condition of men and things in that island are given in yesterday's Times. He says that the streams of mud which are still flowing do not emerge from the flanks of the volcano, but from the constantly convulsed ground, now opening in large abysses and then closing. Evidence that the death of the victims of the Mont Pelée eruption must have been instantaneous was obtained from the appearance of the bodies discovered.

Thus, persons have been found on the thresholds of their nearly demolished houses in the attitude of gazing at Mont Pelée. Others were found seated at a table. One man, dis. covered in the middle of the street, had the muscles of his legs and arms fixed in the attitude of a runner. Others were shaking hands.

\section{PROF. ADOLF FICK.}

WITH Adolf Fick, the physiologist of Würzburg, whose death took place in.the autumn of last year at Blankenberg, there passed away one of the last representatives of the brilliant physiological school by the combined labours and critical acumen of which, during the latter half of the past century, the foundations of modern physiology were established. For the complete appreciation of the man's whole character, however, regard should be had as well to Adolf Fick's energetic and practical support of public, and, in particular, educational questions, as to his distinction as investigator, man of science and teacher. In all matters that he took in hand he made a striking and original appearance, and he merits a special place in the honour roll of history.

Fick, in whom as a youth conspicuous mathematical talent had already displayed itself, sought the university with the intention of studying mathematics. His elder brother, Heinrich, who died a few years ago while professor of Roman law at Zürich, uryed him to the study of medicine, and this he pursued at Marburg and Berlin.

1 Abridged from an obituary notice by Prof. Kunkel. 